\title{
THE CONSEQUENCES OF MOBILE BANKING SERVICES ON CUSTOMER E-SATISFACTION IN PAKISTAN
}

\author{
Samia Shaikh \\ Szabist University, Karachi, Pakistan \\ Soobia Saeed \\ ILMA University, Karachi, Pakistan \\ Muhammad Waqas \\ Lecturar, DHA Suffa University, Pakistan \\ Farooque Ahmed Memon \\ Ilma University, Karachi, Pakistan
}

\begin{abstract}
Purpose: The purpose of this research is to identify the key factors of mobile Banking technology adoption which influence customer E- satisfaction in Pakistan as Mobile banking has manifest itself as an evolving technology adopted by banking industry around the world.

Methodology/Sampling: Multiple Regressions has been used to test the due which is collected through Questionnaire, including questions focusing on Cost Efficiency, Easiness and Security.

Findings: The outcomes of the study suggest that Cost Efficiency, Easiness and Security has significant impact on Customer E-Satisfaction. However, Cost Efficiency and Security are in negative or inversely in relation but easiness factor is in positive relation.

Practical Implications: The study provides better understanding of major factors effecting Customer E-Satisfaction in Mobile banking services. Banks can make their mobile banking services smoother by focusing on these factors to grab the increasing demand of this service.

Keywords: Mobile, Banking services, Customer Satisfaction, Pakistan

Jel Classification: C54, D12, Y1
\end{abstract}

*The material presented by the author does not necessarily portray the view point of the editors and the management of the Ilma University - Formerly IBT

1. Samia Shaikh : ms_shaikh2011@hotmail.com

2. Soobia saeed : soobia_saeed123@hotmail.com

3. Muhammad Waqas : Muhammad.waqas@dsu.edu.pk

4. Farooque Ahmed Memon : farooqmemon@gmail.com

CILMA-JBS is published by the Ilma University - Formerly IBT

Main Ibrahim Hydri Road, Korangi Creek, Karachi-75190, Pakistan 


\section{INTRODUCTION}

\subsection{Overview}

In the current era banking services has become very viable and advanced all around the world. Nowadays banking services covers all the factors to provide facilities to their customers such as mobile banking, online banking and the most important Alternative Delivery channel services. It is also a fact that in current mobile communication all over the world is not considered as luxury but it becomes the basic necessity. Now each and every single person or individual in the society have or possess his/her own a cell phone. Modern Banking has introduced the latest technology "Mobile Banking Services" which now become a way of communication between the customers and banks for handling, making and supervisory the financial transactions. In the this era of the globalization \& with growing competition in almost every sector, number of organizations have reviewed their strategies so that they can provide better facilities to their customers around the globe \& clock with easiness \& cheaper.

Customer Satisfaction is the most \& significant aspect for the future accomplishment of the organization, having this phenomenon in mind banking service sector has to keep close \& healthy relationship with their customer and facilitate them with high quality products \&services. The satisfaction level of the customer cannot be evaluated until the aspects which impact the customer's level of satisfaction have been not determined appropriately.

Kombo F., et.al, (2016), Now in this era the customers has become more demanding and claiming as they want the technology which are more efficient and effective while response of the services. In this perspective many banks globally are seeking and conducting studies for the fresh strategies that assist the online transaction \& sharing of information. These strategies are related to the banking business with their customers by the mobile handsets \& PDA's.

\subsection{Problem Identification}

There are number of problems which are not satisfying the customer in mobile banking services. In this study there are three problems which should be resolved in order to improve the satisfaction of the mobile banking customers in Pakistan.

1. Risk related issues of day-to-day transactions should be effective through which mobile banking services should enables the customers to form faith \& the level of trust in the services being offered by the bank.

2. The amount of facility has not been expanded by the bank consistently which does not motivate the consumers to adopt the banking services, because the technology does not offer uniqueness in their offerings like cost and security.

3. Sophisticated technical infrastructure has not been advanced in order to warrant timeliness provision of services \& reliability to its customers.

\subsection{Background of the Study}

Kaynak, E. \& Harcar, T.D. (2015), The Financial or Banking industry in the Community like Pakistan has been expanded with the introduction of the technology \& the assignments or projects which were initiated by numbers of banks in the country which provides remote rural societies in a country to use banking services. The financial services 
includes money transfers, payment of Utility bills, check amount balance or statement of balance, Bank advisory, report lost banking instruments, mobile recharge/ top up, deals in insurance etc. These services help to decrease mobbing in banking sector $\&$ increase the banking penetration. The customers those use the mobile banking services almost pay the exact fee or charges for their transaction like they pay in the branch banking plus in addition a minor fee for the access of mobile services. Mobile Banking services in fit is a subclass of E- Banking in which customers facilitates by numerous banking products like savings, credit facility via e-channels \& it's necessary before the customer to hold a savings account or deposits from which transfers can be mad.

Mobile Banking is a vital feature since the transactional charges of payments have been decreased significantly and when there is an e-accessible store of value in most regulatory regimes. The concentration is on the broader aspects which were involved in mobile banking services on the high level on developments \& enhancements in the technology \& rule of mpayments. Mobile banking services is serving almost five million customers and will expected to reach in next five years till more than fifty million. Branch less banking is performing almost Rs. 12500 Billion transaction at every month. State Bank of Pakistan has issued twelve licenses to banks for branch less banking from them eight are working and rest of the four banks which includes Bank of Punjab and JS Bank are testing their operation on pilot basis. They are handling overall Twenty four Million transactions in a month.

Barquin, S., \& HV, V. (2015)., According to the Nadeem Hussain, CEO \& President of Tameer Micro Finance Bank, Mobile banking service has revolutionized banking and finance sector of Pakistan, and in future we need to introduce Electronic prize bond, Treasury Bills and virtual gold as investing products for investors. Banking sector should utilize the information technology at maxim level to satisfy and facilitate the customers in order to provide them comfort in their financial transactions.

Husnain, M., \& Akhtar, M. W. (2016), Mobile banking services has many benefits for both providers, banking industry does not need abundant investment \& they do not even have to change their prevailing system and infrastructure. Banks can convey the message in less effort to numerous of people. Mobile banking becomes a good platform for Banks which helps them to make good relations with their customers. Banks also get valued information about their clients which helps them ineffective consumer relationship management practices. It services rapid response $\&$ assistances in customer retaining and its loyalty.

Husnain, M., \& Akhtar, M. W. (2016), When banks possess their customer's info, so they can do advertisement through SMS to provide information about theirservice and newly value added schemes to their standing customers. Through mobile phones customers can be connected to the banking services anytime and anywhere, without wasting their time in lines. Mobile banking is quite cost-effective for customers' and through mobile services information can be stored automatically as a proof in the form of SMS in both sent or received scenario

Academic research on the implementation \&socioeconomic impacts of m-banking and its payments systems in the emerging countries is rare. Even not high attention has been paid to the economic, social \& cultural contexts surrounding the usage of these systems. Since cell phones have become an essential feature of life in Pakistan and world as tools for information, communication and entertainment etc. 
In Pakistan, millions of Pakistanis have downloaded ring tones and games (paid or non-paid) using their cell phones, the phones also serves as a de factor payment tool as because of their easiness, user-friendliness, convenience \& ever-increasing functionality. Mobile phones flourishes and becomes an access to financial services far more complex than these micro payments. Consumers in Pakistan are engaged in using their cell phones to access their bank accounts, top up mobile balance, money transfers, and spending through the facility known as mobile banking. However the phase in development in Pakistan has not been easy as the difficulties posed by the technology \&fast changing trends in the sector carry in the picture of fraud \& malicious software leaves a gap for counterfeit.

\subsection{Significance of the study}

As Pakistan is an emerging market and its telecom industry has increased massively in the last few years. Mobile Technology in Pakistan, had started to grow strongly over the last decades, which witnesses the rapidly increase of consumers to Ninety five million subscribers by the sixth month of 2009 and is still gearing up for additional growth. In Pakistan mobile population has been growing at extraordinary rate of $58 \%$. Public belonging to all wages groups is facilitate by this technology as a outcome overseas investment in telecom Pakistan has been increased and with competitive market which allows the customer to enjoy reduced telecom rates. Banking sector on other hand is motivated by the improvement in technology, market ambiguity and high competition. Sharp shift has been witness has been observed from conventional banking to E-banking in Pakistan. Highly Competitive banks in Pakistan and abroad make high and considerable investments in Adopting new technology to support their business strategies, enabling their innovative functional operations and facilitate their customer extended services. Banks have now started to provide comfort services to the customers a relax and easy daily transactions through mobile banking services. The Mobile Banking services usage have an encouraging prospect which has led researcher to research or study this factor in order to overcome the problems which have been faced by the customers and to take prompt actions as this facility is expected to grow more, so the study going to play a significant role for the more development of the industry.

\subsection{Objectives}

The goal of this research is to measure customer's E-Satisfaction towards the development in the banking services due to the innovation and enlargement in technology and which also discusses the several types of services in current or modern banking which can be useful and necessary to increase or enhance Client E-Satisfaction. In order to measure significance or the impact of Mobile Banking services (Easiness, Security and Cost) on enhancing customer's E-Satisfaction and to give useful \& relevant recommendation and suggestions to the higher management of banks in Pakistan to concerned on mobile banking services in order to increase or enhance the customer e-satisfaction.

\subsection{Outline of the Study}

The modern Banking in the shape of Mobile Banking services become the medium of communication between the banks and their customers to perform the multiple financial transaction. The idea and background of this study has been transcribed in this section of the 
study. Moreover the significance of the study has been that Pakistan being an emerging market and its growing mobile population can be able enjoy the innovation in banking services, which tells us the future outlook of this study that how useful it would be. It enables us to focus on the Customer E-Satisfaction after such innovation in Banking Services.

\subsection{Operational Definitions}

\subsubsection{Dependent variable:}

Customer satisfaction is major of social experience, which reflects the taste of the organization's commercial activities. Customer satisfactions (with pleasurable experiences) on high levels are tough or strong forecasters of customer retaining its loyalty and the product repurchase.

\subsubsection{Independent Variable}

\subsubsection{Easiness}

The quality or condition is easy to accomplish and obtain an ease or relaxation of manner.

\subsubsection{Cost}

An amount that has been recompense or settled up in order to get something and in commercial, rate is generally a monetary estimation of
$\checkmark$ Labor
$\checkmark$ Material
$\checkmark$ Means
$\checkmark$ Period\& values
$\checkmark$ Threats
$\checkmark$ Prospect

All the expenses that have been incurred are charges, but it doesn't mean that all the costs are expenses which have been induct in acquisition of an asset which are able to generate revenue.

\subsubsection{Security}

Security is the system in which measures are taken to safeguard against surveillance or sabotage, crime, attack, or escape.

\section{LITERATURE REVIEW}

Jepleting, A., Sangoro, O., \& Bureti, P. (2013), conducted study on the subject of "Effects of Mobile Banking on Customer Satisfaction". The study was based on gathering primary data by use of questionnaires and interview schedules. The study concluded that Mobile Banking services should make huge efforts towards building trust with customers.

Asfour, H. K. Asfour, H. K., \& Haddad, S. I.(2014), conducted study on the subject of "The Impact of Mobile Banking on Enhancing Customers E- Satisfaction". The study was based on Regression analysis on sample data of 360 customers who use banking services via mobile. 
The study concluded that there is a statically significant impact of Mobile Banking service on E-Satisfaction, privacy and accessibility are more influential factors.

K.C. Lee and N. Chung, (2009), conducted study on the subject of "Understanding factors affecting trust in and satisfaction with mobile banking in Korea: a modified Delone and McLean's model perspective", the study was based on DeLone and McLean's model, evaluation that the factors of three external quality can impact satisfaction \& trust. 260 questionnaires of primary data have been gathered from the customers of mobile banking and then examined the data using structural equation modeling. The study concluded that system quality \& information quality significantly develops customer's satisfaction and trust, and does not interface design quality. Their study presents the consequences and recommendations for advance study.

Khalid A. S. (2012), Conducted study on the subject of "Banking services and Customer Satisfaction in Qatar". The study was based on evaluating the expectations of service quality of the banking customer and to evaluate whether banking services provided by financial institutions are satisfactory to customers of Qatar and it also examines empirically the determinants of the buying behavior of banking customers. The use of questionnaire was designed \& different statistical methods were applied. The study concluded the policy implication from statistical findings is that the management of the bank should focus on their strength and weakness areas to overcome them.

Kahandawa, Wijayanake (2014), conducted study on the subject of "Impact of Mobile Banking services on Customer Satisfaction". The study was based on gathering primary data using a questionnaire. The study concluded that customer of Mobile Banking Services satisfaction is influenced by usefulness ease of use, relative advantage, perception on risk and user lifestyle and customer's need.

M. Rizwan, et.al, (2014), conducted study on the subject of "Modern Banking and Customer Satisfaction". The study was based on survey based questionnaire sample size of 120 bank users. The study concluded the variables as security, awareness, ease of use and trust have moderate relationship with the customer satisfaction.

Nupur, J. M. (2010), Conducted study on the subject of "E-Banking and Customers' Satisfaction in Bangladesh: An Analysis". This research was based on the different service quality proportions that is consistency, approachability, reassurance, understanding, and tangibles have been recognized based on the SERVQUAL model. The data were gathered from two hundred and fifty customers through means of interview by a questionnaire through survey. The study concluded that these are the essential service quality dimensions for customer's e-banking satisfaction and also identify the reliability; assurance \& responsiveness have contributed to satisfy the customers in Bangladesh.

Ching Poon (2007) conducted study on the subject of "User adoption of E-Banking Services; the Malaysian Perspective". The study was based on questionnaire survey of 324 people and ten factors are tested that is ease of practice, user-friendliness, features obtainability, goodwill, safety, confidentiality, strategy, contented, rapidity, payments \&duties. This research concluded that the all the features for given recognized factors are important with esteem to the consumer's acceptance of the E-Banking services. 
S. BhalchandraSaoji and P. Kumar Goel, (2013), conducted study on the subject of "Understanding customer response and customer satisfaction of mobile banking in India". The investigation depends on high love between apparent esteem and administration characteristics with the consumer loyalty in portable managing an account. There are various variables that decide the consumer loyalty of versatile saving money in India and they are proficiency, security, cost adequacy, fulfillment, and issue taking care of and precise in result. This audit closes on investigating the client reaction and the fulfillment of portable standard bank through these components.

Saleh Salari and Moslem Salajegheh.(2011), Conducted study on the subject of "Analysis of Factors Affecting the Adoption of Internet Banking. Case Study: Customers of Mellat Bank inIsfahan City". The study is based on analyzing the factors affecting the acceptance of Internet banking at Mellat bank branches in City of Isfahan. The improved model of technology acceptance model (TAM) is used. This research concluded that adoption of E-banking is mostly affected by faith, user-friendliness, perceived utility, and approach\& tends to use.

T. Laukkanen \& J. Lauronen.(2005), Conducted study on the subject of "Customer value making in m-banking services". The purpose of the research is toexplore or finds the value making in different m-banking services. It is the research based on exploratory which is conducted on proficient in E-banking service consumers by means of a qualitative in depth interviewing method. This research concluded on the finding that suggests specialists to advance their services \& marketing tactics\& pass on innovative info to the academics about stimulating upcoming study spaces.

Thulani, D.et.al, (2011), conducted study on the subject of "Adoption and Use of SMS/Mobile Banking Services". This research is based on exploratory research design was used for the study to examine the outcome or advantages of the SMS banking and the difficulties tackled by banks with the view of adopting this emerging technology as an alternative delivery channel. The primary data were used to illustration of fifteen banks which was designated plus those presented the service \& for the ones which are planning to introduce SMS banking services. The research concluded co the declaration that the demand is more about accessibility \&cost efficiency in under developed country and this has been the reason due to lack of regulation for e-banking in Zimbabwe. The study recommended an increased awareness campaign by banking industry \& development of policy and regulation for E-banking in Zimbabwe.

T. Sadeghi.et.al, (2010), conducted study on the subject of "Customer satisfaction factors (CSFs) with E-banking services in Iran". The study depended on researching the significant aspects fundamental consumer loyalty with e-saving money offices in Iran. The study reasoned that model of seven factors on the accompanying measurements: openness, ease of use, exactness, security, convenience, altruism, and web composition are highlights of client's quality perception benefits in e-keeping money and this exploration displays new rules in benefit quality research \&proposals reestablished approaches to scientists and administration in giving better-quality administrations. These a few angles delineate a huge factual distinction between both the sexual orientations.

Yi-Shun Wang, et.al, (2003) conducted study on the subject of "Determinants of user acceptance of sites bank: an empirical study". This kind of study is based on acceptance model (TAM) as a theoretical framework, this study introduces "perceived credibility" as a new factor that shows security of the user\& privacy concerns in the adoption of Internet 
banking. In addition, it interprets the result of computer self-efficacy on the goal to use Ebanking. The data were gathered on the sample of One hundred or so \& twenty three internet banking users through a telephonic interview, the last outcome powerfully sustenance the extended TAM in guessing the essence customers to agree to E-banking.

Ghazi, S. R.(2011), Conducted study on the subject "Relationship between Customer Satisfactions and Mobile Banking Adoption in Pakistan". This research is based on the purpose is to identify the important features of m-technology acceptance which result in consumer's fulfillment level in Pakistan. Primary data has been collected through questionnaires \& then investigated by means of statistical techniques: regression analysis, correlation and factor analysis. The study concluded on customer's concerns about safety, legitimacy and consistency of the technology are vital\& the outcomes measure that organizations should emphasis on the use of the IT, advanced services, safety, trust of the customer and threats.

\subsection{Hypotheses of the Study}

H1: Cost Efficiency has significant impact on Customer E-Satisfaction.

H2: Easiness has significant impact on Customer E-Satisfaction.

H3: Security has significant impact on Customer E-Satisfaction

\section{RESEARCH METHODOLOGY}

\subsection{Method of Data Collection}

Primary sources have been used for the collection of data. A Close ended questionnaire has been used as a tool to collect data from respondents. Five options is used for the answers of Questionnaire which are strongly disagree, disagree, neutral, agree and strongly agree. A code has been given for the each option which is used in sample tests.

\subsection{Sampling technique}

In this study data collection technique has been used (Non-Probability based) and convenient sampling. Sample of 170 respondents has been taken from various institutions for survey interview.

\subsection{Statistical Test applied}

The data collected through questionnaire by medium of survey has been tested for reliability before applying any statistical test, reliability test has been applied to test the reliability of data collected through questionnaire. After checking the reliability, Regression Model has been applied.

\subsection{Research Model (Frame work)}

Since the study inspects the impact and consequences of Mobile Banking Services factors on Customer E-Satisfaction. The simple Regression model can be expressed as:

$$
Y=\beta_{0}+\beta_{1} X_{1}+\beta_{2} X_{2}+\beta_{3} X_{3}+\ldots \ldots \ldots \ldots \ldots \ldots+\ldots
$$


As this study was made to inspect the influence of different factors on Customer ESatisfaction, therefore these factors has been used in Regression model:

Cost Efficiency (CE)

Easiness (E)

Security (S)

Therefore the Regression Model becomes as follows according to my study:

$\mathrm{BE}=\beta_{0}+\beta_{1} \mathrm{CE}+\beta_{2} \mathrm{E}+\beta_{3} \mathrm{~S}+$

\section{$\underline{\text { Customer E-Satisfaction }}$}<smiles>C1CCCC1</smiles>

Cost Efficiency<smiles>C1CC2CCC12</smiles>

Easiness<smiles>C1CC2CCC12</smiles>

Security

\section{RESULTS OF THE STUDY}

\subsection{Reliability of Model: Interpretation of Reliability test and ANOVA}

\section{Table 1: Reliability Statistics}

\begin{tabular}{|l|l|}
\hline Cronbach's Alpha & N of Items \\
\hline .540 & 4 \\
\hline
\end{tabular}

The value of Cronbach's Alpha (0.540) is greater than 0.5 that suggests that Categorical Data used is Reliable for Linear Regression Analysis. On the basis of Reliability test, now the Regression analysis may be made to investigate the effect of Mobile Banking Services on Customer E-Satisfaction in Pakistan.

Table 2: ANOVA ${ }^{\text {b }}$

ANOVA $^{b}$

\begin{tabular}{|l|llllll|}
\hline \multicolumn{2}{|l}{ Model } & $\begin{array}{l}\text { Sum of } \\
\text { Squares }\end{array}$ & df & $\begin{array}{l}\text { Mean } \\
\text { Square }\end{array}$ & F & Sig. \\
\hline \multirow{1}{*}{1} & Regression & 3.735 & $\mathbf{3}$ & 1.245 & 7.678 & $.000^{\mathrm{a}}$ \\
\cline { 2 - 7 } & Residual & 26.920 & 166 & .162 & & \\
\cline { 2 - 7 } & Total & 30.656 & 169 & & & \\
\cline { 2 - 7 } & & &
\end{tabular}


Predictors: (Constant), Security, Easiness, Cost Efficiency

Dependent variable: Customer Satisfaction

Table 3: Dependent Variable: Customer E-Satisfaction

\begin{tabular}{|l|llllll|}
\hline Model & & \multicolumn{2}{l}{$\begin{array}{l}\text { Unstandardized } \\
\text { Coefficients }\end{array}$} & $\begin{array}{l}\text { Standardized } \\
\text { Coefficients }\end{array}$ & & \\
\cline { 3 - 8 } & & $\mathrm{B}$ & Std. Error & Beta & $\mathrm{t}$ & Sig. \\
\hline $\mathbf{1}$ & (Constant) & 1.572 & .164 & & 9.590 & .000 \\
\cline { 2 - 8 } & Cost_Efficiency & -.167 & .072 & -.213 & -2.336 & .021 \\
\cline { 2 - 7 } & Easiness & .462 & .098 & .415 & 4.734 & .000 \\
\cline { 2 - 7 } & Security & -.065 & .052 & -.100 & -1.245 & .215 \\
\hline
\end{tabular}

The result of ANNOVA as shown in table 2 is significant, since sig value is less than 0.05 . Because sig value is less than 0.05 showing that Regression Model is significant. The result of Reliability Test and ANNOVA test are significant hence the justifying for the significance of the Regression Model. The Results of the Model are presented in Table 3.

H1: Cost Efficiency has significant impact on Customer E-Satisfaction.

The sig value of the Beta Coefficient of Cost Efficiency is less than 0.05, showing that there is significant effect of Cost Efficiency on Customer E-Satisfaction. Therefore, $\mathrm{H} 1$ is accepted that is significant effect of Cost Efficiency on Customer E-Satisfaction in Pakistan. More ever, negative value of Beta shows that there is significant inverse effect of Cost Efficiency on Customer E-Satisfaction in Pakistan.

H2: Easiness has significant impact on Customer E-Satisfaction.

The sig value of the Beta Coefficient of Easiness is less than zero. 05, showing that there is significant effect of Easiness on Customer E-Satisfaction. Consequently, $\mathrm{H} 2$ is accepted there is significant impact of Easiness on Buyer E-Satisfaction in Pakistan. Even more ever, positive value of Beta shows that there may be significant Positive effect of Easiness on Customer E-Satisfaction.

H3: Security has significant impact on Customer E-Satisfaction.

The sig value of the Beta Coefficient of Secretes is more than zero. 05, showing that there is no significant impact of Security on Consumer E-Satisfaction. Therefore, H3 is rejected that there is no significant effect of Security on Customer E-Satisfaction in Pakistan. More at any time, negative value of Beta shows that there is negative effect of Protection on Customer ESatisfaction. 


\subsection{Hypotheses Assessment Summary}

Table 4.2 Hypotheses Assessment Summary

\begin{tabular}{|ccccc|}
\hline $\begin{array}{c}\text { Hyp. } \\
\text { No }\end{array}$ & Hypothesis & $\begin{array}{c}\text { Beta } \\
\text { Coefficient }\end{array}$ & $\begin{array}{c}\text { Sig } \\
\text { Value }\end{array}$ & $\begin{array}{c}\text { Empirical } \\
\text { Conclusion }\end{array}$ \\
\hline $\mathbf{1}$ & $\begin{array}{c}\text { There is significant effect of Cost Efficiency } \\
\text { on Customer E-Satisfaction but in inverse } \\
\text { relation. }\end{array}$ & -.213 & .021 & Accepted \\
\hline $\mathbf{2}$ & $\begin{array}{c}\text { There is significant effect of Easiness on } \\
\text { Customer E-Satisfaction. }\end{array}$ & .415 & .000 & Accepted \\
\hline $\mathbf{2}$ & $\begin{array}{c}\text { There is no significant effect of Security on } \\
\text { Customer E-Satisfaction. }\end{array}$ & -.100 & .215 & Rejected \\
\hline
\end{tabular}

\section{DISCUSSION AND CONCLUSION}

\subsection{Discussion}

The Survey based Analysis has been investigated statistically. The Regression based Model has been deployed to test the results. The validity of the Model has been tested via Reliability Test and ANNOVA Test. In this research, the author discussed and the conclusion shall be provided in Specific Statistical analysis in detail.

The respondents were interviewed to determine influence of Cost Efficiency on Customer ESatisfaction. The Study provides that there is significant effect of Cost Efficiency on Customer E-Satisfaction. More ever, negative value of Beta shows that there is significant inverse effect of Cost Efficiency on Customer E-Satisfaction in Pakistan.

The Survey was deepened by inquiring about the effectiveness of Easiness on Customer ESatisfaction. The study suggests that there is significant effect of Easiness on Customer ESatisfaction. More ever, positive value of Beta shows that there is significant Positive effect of Easiness on Customer E-Satisfaction in Pakistan.

The Study was now focused on evaluating the effect of Security on Customer E-Satisfaction. The study shows that there is no significant impact of Security on Customer E-Satisfaction. More ever, negative value of Beta show that there is negative effect of Security on Customer E-Satisfaction in Pakistan.

\subsection{Conclusion}

The Regression Analysis based on Survey Approach provides crucial results that may be added for Customer E-Satisfaction in Mobile Banking services. The respondents were interviewed to determine the consequences of Mobile Banking Services on Customer ESatisfaction in Pakistan. The Study concludes that there is significant negative effect of Cost Efficiency on Customer E-Satisfaction in Pakistan

The detailed analysis was made by investigating the effectiveness of Easiness on Customer E-Satisfaction. The study concludes that there is significant positive effect of Easiness on Customer E-Satisfaction in Pakistan. 
The comprehensive analysis was made by measuring the impact of Security on Customer ESatisfaction. The study concludes that there is no significant positive effect' of Easiness on Customer E-Satisfaction in Pakistan.

\subsection{Implications}

This study focuses in viability of Mobile Banking administrations on Customer level of fulfillment. The conclusion might be connected and utilized as a part of cutting edge Mobile keeping money administrations. The investigation depicts obviously the part of MBanking administrations on Customer's E-Satisfaction.

\subsection{Future research}

For the future, study can be conducted on different factors which impact the Banking industry performance on customer's level of satisfaction on their services as it is indicated that there are other factors which may impacts banking performance.

\section{REFERENCES}

Kombo F., Paulík J. and Kwarteng A. M. (2016). E-Banking Functionality as a Measure of Customer Satisfaction In The Czech And Kenyan Banking Sectors. International Journal of Business and Commerce, 1(10): 82-105.

Kaynak, E. \& Harcar, T.D. (2015). Consumer Value Creation in Mobile Banking Services', International Journal of Technology Marketing, 1(1): 62-78.

Barquin, S., \& HV, V. (2015). Digital Banking in Asia: What do consumers really want?

McKinsey \& Company. Bebli, R. S. (n.d.). The Impact of internet banking service quality on customer satisfaction in the banking sector of Ghana. School of Management,2(1):2930 .

The Impact of E-Banking on Customer Satisfaction: Evidence from Banking Sector of Pakistan. Available from: https://www.researchgate.net/publication/308093559_The_Impact_of_EBanking_on_Customer_Satisfaction_Evidence_from_Banking_Sector_of_Pakistan

Husnain, M., \& Akhtar, M. W. (2016). Impact of Branding on Impulse Buying Behavior: Evidence from FMCG's Sector Pakistan. International Journal of Business Administration, 7(1):59. http://dx.doi.org/10.5430/ijba.v7n1p59

The Impact of E-Banking on Customer Satisfaction: Evidence from Banking Sector of Pakistan. Available from: https://www.researchgate.net/publication/308093559_The_Impact_of_EBanking_on_Customer_Satisfaction_Evidence_from_Banking_Sector_of_Pakistan

Jepleting, A., Sangoro, O., \& Bureti, P. (2013). Effects of mobile banking on customer satisfaction. a case of Equity Bank of Eldoret town. International Journal of Innovative Research In Management, 2(3):29-40.

Asfour, H. K., \& Haddad, S. I. (2014). The Impact of Mobile Banking on Enhancing Customers' E-Satisfaction: An Empirical Study on Commercial Banks in Jordan. International Business Research, 7(10):145. 
K.C.Lee and N. Chung, (2009).Understanding factors affecting trust in and satisfaction with mobile banking in Korea: a modified Delone and McLean's model perspective, interacting with Computers, 21 (6): 385-92.

KhalidA.S,Wijayanayake,J.(2014). Banking Services and Customer's Satisfaction in Qatar: A Kahandawa, K., \&. Impact of Mobile Banking Services on Customer Satisfaction: A Study on Sri Lankan State Commercial Bank. International Journal of Computer and Information Technology, 3(3): 546-52.

Rizwan, M., Rehman, A., Rizivi, A., Khan, R., Ayuub, S., Baloch, U., \& Sardar, B. (2014). Modern Banking and Customer Satisfaction. Journal of Finance and Accounting, 2(3): $1-20$.

Poon, W. C. (2007).User's adoption of E-Banking services: the Malaysian perspective. Journal of Business \& Industrial Marketing, 23(1): 59-69.

Nupur, J. M. (2010). E-banking and customers' satisfaction in Bangladesh: An analysis. International review of business research papers, 6(4):145-156.

S. BhalchandraSaoji and P. Kumar Goel, January (2013). Understanding customer response and customer satisfaction of mobile banking in India. International Journal of Advanced System and Social Engineering Research, 3(1):1-5.

Saleh Salari and Moslem Salajegheh.(2011). Analysis of Factors Affecting the Adoption of Internet Banking. Case Study: Customers of Mellat Bank in Isfahan City. International Conference "Risk in Contemporary Economy. ISSN 2067-0532

T. Laukkanen \& J. Lauronen.(2005). Consumer value creation in mobile banking services" .International Journal of Mobile Communication, 3(4):12-13.

Thulani, D., Kosmas, N., Collins, M., \& Lloyd, C. (2011). Adoption and Use of SMS/Mobile Banking Services. Journal of Internet Banking and Commerce, 16(2):1-5.

T. Sadeghi \&K.Heidarzadeh Hanzaee, (2010). Customer satisfaction factors (CSFs) with online banking services in an Islamic country: I.R. Iran, Journal of Islamic Marketing, 1(3):249 - 267.

Y. Shun Wang, Y. Min Wang, H. -Hui Lin\& T.-I Tang, (2003). Determinants of user acceptance of Internet banking: an empirical study", International Journal of Service Industry Management, 14 (5):501 - 519.

Ghazi, S. R., Shahzada, G., Gilani, U. S., Shabbir, M. N., \& Rashid, M. (2011). Relationship Between Students'self Perceived Multiple Intelligences And Their Academic Achievement. International Journal of Academic Research, 3(2):11-14. 